\title{
MEMBANGUN KAMPUNG BERBASIS DATA (Pendampingan Penyusunan Monografi dan Profil Kampung Yobeh Distrik Sentani Kabupaten Jayapura)
}

\author{
Jackson Yumame ${ }^{1}$, Ilham $^{2}$, Dorthea Renyaan ${ }^{3}$, Hiskia Sapioper ${ }^{4}$ \\ 1,2,3,4) Program Studi Ilmu Administrasi Publik Fakultas Ilmu Sosial dan Ilmu Politik Universitas \\ Cenderawasih Jayapura-Papua \\ e-mail: jackson_yumame@yahoo.co.id
}

\begin{abstract}
Abstrak
Pada bulan September, 2020, Kegiatan Pengabdian kepada Masyarakat dilaksanakan dengan melibatkan dosen dan mahasiswa angkatan 2017 pada Program Studi Ilmu Administrasi Publik, Fakultas Ilmu Sosial dan Ilmu Politik, Universitas Cenderawasih. Kegiatan ini bertajuk "Membangun Kampung Berbasis Data" (Pendampingan Penyusunan Monografi dan Profil Kampung Yobeh Distrik Sentani Kabupaten Jayapura) melalui pendekatan "Partisipatif dan Edukatif". Pelaksanaan kegiatan ini merupakan bentuk fasilitasi dan implementasi Peraturan Menteri Dalam Negeri Nomor 13 Tahun 2012 tentang Monografi Desa Dan Kelurahan serta Peraturan Menteri Dalam Negeri Nomor 12 Tahun 2007 tentang Pedoman Penyusunan Dan Pendayagunaan Data Profil Desa Dan Kelurahan. Pada saat dilakukan survei lokasi terkuak bahwa Kampung Yobeh belum memiliki Profil dan Monografi sebagai sumber informasi potensi kampung. Mengingat pentingnya akurasi data dalam perencanaan agar pembuatan kebijakan pembangunan dapat tepat sasaran, dan selaras dengan kebutuhan masyarakat maka dinilai penting untuk dilakukan pendampingan sebagai bahagian dari pelaksanaan "Tri Dharma" Perguruan Tinggi, salah satunya adalah pengabdian kepada masyarakat..
\end{abstract}

Kata Kunci: Monografi, Profil Kampung, Data, Pembangunan

\begin{abstract}
On September 2020, both lectures and students (class of 2017) of the study program of Public Administration Science, Faculty of Social and Political Sciences of the University of Cenderawasih conducted the community service activities. The tittle of this activity is \&quot;The Development of the Village-Based On Data \&quot; (Mentoring the Design of Monographs and the Profiles of Yobeh Village in Sentani District, Jayapura Regency). The method used in this community service is \&quot;Participatory and Educational\&quot; approach. Moreover, the implementation of this activity based on the Regulation of the Minister of Home Affairs No. 13 of 2012 about Village Monograph and Regulation of the Minister of Home Affairs No. 12 of 2007 regarding the Guidelines for The Preparation and The Use of Village Profile Data. Based on the early survey, it was found that Yobeh Village did not has Profile and Monograph yet as a potential source of information for the village. This issue is important because data accuracy is very crucial in development planning. Thus, through data, it can support policymaking to formulate and implement the policy based on the needs of the community. So, it is considered important to conduct mentoring and training of profiling and monographing the village of Yobeh which is part of the implementation of "Tri Dharma Perguruan Tinggi" and one of them is community service.
\end{abstract}

Keywords: Monograph, Village Profile, Data, Development

\section{PENDAHULUAN}

Desa merupakan lembaga pemerintahan yang berada paling bawah dalam sistem pemerintahan Republik Indonesia. Asal mula kata desa berasal dari bahasa sansekerta "Deshi" yang berarti tanah kelahiran atau tanah tumpah darah, (Widodo, 2015). Desa atau dikenal dengan istilah kampung di wilayah Papua menurut Undang-undang nomor 6 Tahun 2014 tentang Desa dapat diartikan bahwa 
desa adat atau yang disebut dengan nama lain selanjutnya disebut Desa adalah kesatuan masyarakat hukum yang memiliki batas wilayah yang berwenang untuk mengatur dan mengurus urusan pemerintahan, kepentingan masyarakat setempat berdasarkan prakarsa masyarakat, hak asal usul, dan/atau hak tradisional yang diakui dan dihormati dalam sistem pemerintahan Negara Kesatuan Republik Indonesia, (Ilham, Muttaqin, \& Idris 2020).

Dalam teritorial Negara Indonesia terdapat lebih kurang 250 "Zelfbesturende landschappen" dan "Volksgemeenschappen", seperti desa di Jawa dan Bali, Nagari di Minangkabau, dusun dan marga di Palembang, dan sebagainya. Daerah-daerah itu mempunyai susunan Asli dan oleh karenanya dapat dianggap sebagai daerah yang bersifat istimewa. Negara Republik Indonesia menghormati kedudukan daerah-daerah istimewa tersebut dan segala peraturan negara yang mengenai daerah-daerah itu akan mengingati hak-hak asal usul daerah tersebut, (Turmudi, Harun, \& .Nurhadiantomo, 2017). Di Papua perubahan istilah desa menjadi kampung juga terjadi sejak diimplementasikannya Undang-undang Nomor 21 Tahun 2001 tentang pemberlakuan Otonomi Khusus (Otsus) bagi Provinsi Papua, selain perubahan istilah desa menjadi kampung termasuk adanya perubahan dari kecamatan menjadi distrik, (Anangkota, 2013).

Papua merupakan provinsi paling timur Indonesia yang berbatasan langsung dengan Negara Papua New Guinea, Papua memiliki kondisi alam yang cukup sulit terpencil dan terisolasi. Berbagai langkah dan upaya kemudian dilakukan oleh pemerintah pusat dan daerah dalam rangka mengeluarkan Papua dari belenggu isolasi, salah satunya adalah dengan menggenjot pembangunan infrastruktur. Hal ini merupakan wujud implementasi konsep membangun dari pinggiran yang telah ramai menjadi perbincangan publik sejak tahun 2014, Presiden Joko Widodo dengan Nawacita (sembilan agenda) yang ditawarkan salah satu adalah membangun Indonesia dari pinggiran dengan memperkuat daerah-daerah dan desa dalam kerangka negara kesatuan. Pembicaraan mengenai pembangunan desa, sesuai amanat Undang-undang Nomor 6 Tahun 2014 tentang Desa, pembangunan perdesaan ditujukan untuk meningkatkan kesejahteraan dan kualitas hidup masyarakat desa. Caranya, dengan mendorong pembangunan desa-desa mandiri dan berkelanjutan yang memiliki ketahanan sosial, ekonomi, dan lingkungan, (Setkab.go.id, 2019).

Pembangunan dilakukan dengan tujuan untuk mensejahterakan masyarakat, dalam artian buah hasil dari pembangunan dapat dinikmati oleh masyarakat. Sejatinya pembangunan yang mensejahterakan akan terwujud ketika dilakukan dengan baik dan tepat sasaran. Untuk itu, basis data sebagai sumber informasi menjadi suatu keniscayaan dalam menciptakan pembangunan yang sesuai dengan kebutuhan masyarakat atau selaras dengan kearifan lokal. Data bukan hanya sebatas angka atau kebutuhan administrasi yang harus dipenuhi, melainkan dapat dimaknai sebagai wadah pencapain visi dan misi pemerintah desa. Berangkat dari uraian tersebut, maka penting suatu desa memiliki monografi dan profil kampung, tentunya hal ini juga sebagai wujud implementasi Peraturan Menteri Dalam Negeri Republik Indonesia Nomor 13 Tahun 2012 tentang Monografi Desa Dan Kelurahan. Dan Peraturan Menteri Dalam Negeri Nomor 12 Tahun 2007 tentang Pedoman Penyusunan Dan Pendayagunaan Data Profil Desa Dan Kelurahan.

Peraturan Menteri Dalam Negeri Republik Indonesia Nomor 13 Tahun 2012 menjelaskan bahwa Monografi desa dan kelurahan adalah himpunan data yang dilaksanakan oleh pemerintah desa dan kelurahan yang tersusun secara sistematis, lengkap, akurat, dan terpadu dalam penyelenggaraan pemerintahan. Monografi desa dan kelurahan selanjutnya memuat tentang data umum, personil, kewenangan, keuangan dan kelembagaan. Dalam Peraturan Menteri Dalam Negeri Nomor 12 Tahun 2007 dijelaskan pula bahwa profil desa adalah gambaran menyeluruh tentang karakter desa dan kelurahan yang meliputi data dasar keluarga, potensi sumber daya alam, sumber daya manusia, kelembagaan, prasarana dan sarana serta perkembangan kemajuan dan permasalahan yang dihadapi desa dan kelurahan. Kendati monografi dan potensi./profil desa merupakan dua hal yang penting sebagai sumber informasi dalam pelaksanaan pembangunan desa, tetapi pemerintah desa masih cenderung menganggap hanya sebagai kelengkapan administrasi yang harus ditunaikan sehingga dalam penyusunannya masih belum serius. Alhasil data yang disajikan kurang akurat sesuai dengan perkembangan yang terjadi dalam suatu wilayah desa.

Pemerintah desa bisa bermitra dengan Perguruan Tinggi atau lembaga Non Government Organization (NGO), yang dapat dijadikan sebagai pendamping saat proses pembuatan profil desa dan monograf. Selain membutuhkan pendampingan, komunikasi antara pemerintah desa dengan masyarakat juga penting, pelbagai perwakilan pihak yang ada di desa hendaknya dilibatkan dalam 
proses penyusunan sehingga partisipasi masyarakat dapat ditampung secara menyeluruh, sebab jangan sampai data desa hanya berhenti dalam bentuk monografi dan profil desa saja,(Masterplandesa.com, 2020). Berangkat dari penjelasan diatas, maka selanjutnya dianggap urgen untuk dilakukan pendampingan dalam pemetaan potensi, penyusunan profil dan monografi desa/kampong sebagai bentuk pengabdian kepada masyarakat yang dilaksanakan di Kampung Yobeh, Distrik Sentani, Kabupaten Jayapura, Provinsi Papua..

\section{METODE}

Pelaksanaan kegiatan Pengabdian kepada Masyarakat (PkM), penting adanya suatu metode yang digunakan sebagai landasan atau cara yang ditempuh dalam pencapain tujuan yang telah terencanakan sebelumnya. Adapun metode yang digunakan pada kegiatan pengabdian masyarakat yang mengusung tema "Membangun Kampung Berbasis Data" (Pendampingan Penyusunan Monografi Dan Profil Kampung Yobeh Distrik Sentani Kabupaten Jayapura), yakni melalui pendekatan "Partisipatif dan Edukatif". Partisipatif merupakan pelibatan aparatur kampung dan masyarakat mulai dari tahapan perencanaan, proses pelaksanaan, hingga pada tahap evaluasi setiap program kerja. Edukatif sendiri dimaknai sebagai upaya memasukkan unsur pendidikan pada pelaksanaan kegiatan, atau dengan menanamkan pemahaman kepada mitra melalui pelatihan penyusunan dan penginputan yang kaitannya dengan profil dan monografi kampung.

\section{HASIL DAN PEMBAHASAN Tahapan Kegiatan}

Kegiatan ini melibatkan dosen dan mahasiswa angkatan 2017 pada Program Studi Ilmu Administrasi Publik Fakultas Ilmu Sosial dan Ilmu Politik Universitas Cenderawasih JayapuraPapua. Lokasi pengabdian dipusatkan di Kampung Yobeh Distrik Sentani Kabupaten Jayapura yang berlangsung sejak 31 Agustus hingga 5 September 2020. Mengingat pelaksanaannya dalam masa pandemi Coronavirus Disease 2019 (Covid-19) yang turut berdampak di Provinsi Papua, sehingga mekanisme pelaksanaan dilakukan dengan membagi tim kedalam bentuk kelompok dan membatasi jumlah mahasiswa yang terlibat dalam setiap tahapan kegiatan. Karena masa pandemi, maka kegiatan dilaksanakan dengan mengedepankan protokol kesehatan yakni; mengenakan masker, mencuci tangan, menjaga jarak fisik (physical distancing), yang telah menjadi himbauan pemerintah sebagai upaya memutus mata rantai penyebaran Covid-19 di Indonesia. Kegiatan pengabdian ini diawali dengan pembentukan tim, melakukan survei lokasi, mendiskusikan rencana program dengan mitra, perumusan rencana kerja, pelaksanaan kegiatan, evaluasi dan penyusunan laporan akhir. Untuk lebih jelasnya, adapun tahapan kegiatan dapat dilihat pada gambar alur pelaksanaan kegiatan berikut ini :

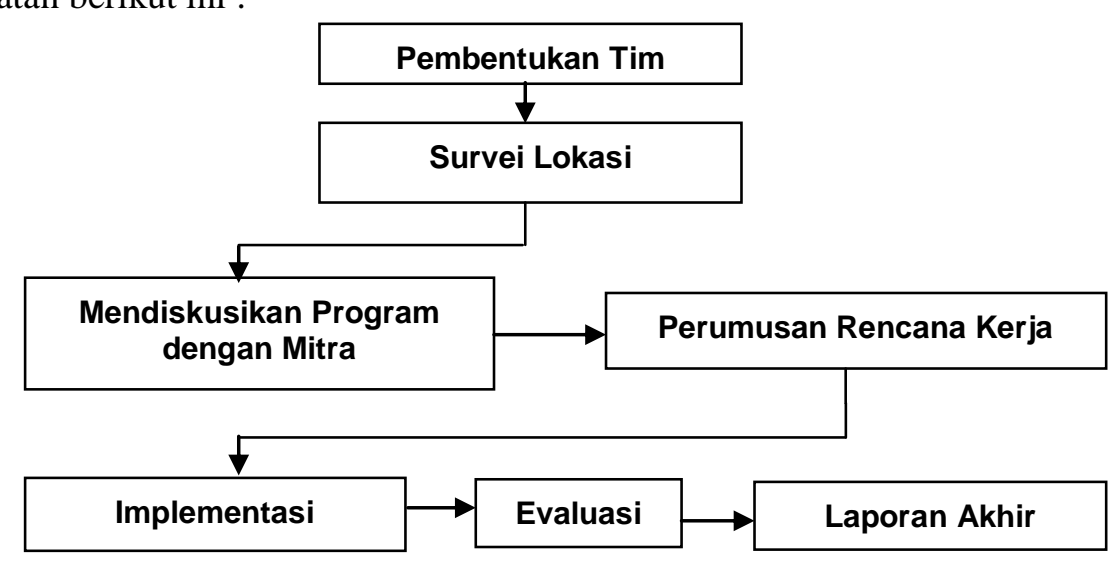

Gambar. 1 : Alur Kegiatan Pengabdian Kepada Masyarakat

Akurasi dan aktualitas data serta tingkat kemampuan perangkat kampung menjadi hal penting dalam penyusunan profil dan monografi kampung. Untuk itu, setiap tahapan pelaksanaan pengabdian ini dikemas dalam bentuk partisipatif dan edukatif, dengan tujuan: pertama, meningkatkan kemampuan perangkat kampung dalam memetakan potensi, mengisi profil dan monografi melalui pendidikan dan pelatihan pengumpulan data, penyusunan profil dan pengisian 
monografi desa/kampung; kedua, meningkatkan kesadaran masyarakat untuk melaporkan semisal terjadi perubahan data, dengan adanya kesadaran dan partisipasi masyarakat dalam melaporkan data bila terjadi perubahan maka akan mempermudah dalam melakukan pembaruan data, serta; ketiga; pelibatan para ketua RW/RT dalam melakukan pendataan dan menginventarisir sumber daya kampung, baik dari segi sumber daya alam begitu juga dengan sumber daya manusianya.

\section{Pembahasan}

Pada tahun 2020, Indonesia merupakan negara dengan jumlah penduduk terbesar ke 4 (empat) di dunia. Berdasarkan angka statistik worldometer.info yang dibuat oleh perusahaan media digital berbasis di Amerika Serikat merilis bahwa China menduduki peringkat pertama dengan jumlah penduduk sekitar 1,44 miliar, kemudian dibuntuti oleh India dengan jumlah penduduk sekitar 1,382 miliar, menyusul Amerika Serikat sebesar 331,3 juta, Indonesia sendiri mencapai 273,9 juta, serta dibawahnya ada Pakistan dengan jumlah penduduk berkisar 221,5 juta jiwa. American Library Association yang merupakan asosiasi perpustakaan tertua dan terbesar di dunia menyebutkan jika worldometer.info merupakan situs referensi gratis terbaik, (Detikcom, 2020).

Menurut Wirayadnya, (2011) bak dua sisi mata uang, penduduk yang besar akan menjadi sumber daya yang sangat penting untuk dikembangkan guna mendukung pembangunan, jika potensi tersebut tidak diketahui dengan detail, maka akan muncul sisi mata uang lainnya, jumlah penduduk yang besar tanpa dukungan data yang akurat akan mengakibatkan kegiatan pembangunan tidak tepat sasaran. Senada, Kepala Badan Pusat Statistik Provinsi Papua, Simon Sapari sebagaimana dikutip dari situs resmi Pemerintah Kabupaten Jayapura disebutkan bahwa data itu mahal, tetapi lebih mahal lagi membangun tanpa data, (Jayapurakab.go.id, 2017).

Bertolak dari beberapa pendapat diatas, untuk mewujudkan perencanaan dan pelaksanaan kegiatan pembangunan yang tepat sasaran, maka akurasi data adalah menjadi suatu keniscayaan. Profi kampung yang di dalamnya terdapat data dasar keluarga, data potensi kampung, dan data perkembangan desa/kelurahan menjadi acuan atau basis data dalam penyusunan program atau perencanaan pembangunan di tingkat kampung. Sementara monografi desa/kelurahan bertujuan menyajikan data administrasi desa secara umum, personal, kewenangan, termasuk keuangan dan kelembagaan. Dengan adanya monografi desa merupakan salah bentuk transparansi pengelolaan keuangan, dimana masyarakat dapat memperoleh informasi mengenai pengelolaan keuangan desa secara lengkap dengan adanya data yang disajikan melalui monografi.

\section{Mengenal Lokasi PKM "Kampung Yobeh"}

Yobeh merupakan salah satu kampung yang berada dalam wilayah Distrik Sentani, Kabupaten Jayapura. Waktu tempuh menuju Kantor Distrik selama 15 menit, untuk menuju Kantor Bupati Jayapura dibutuhkan waktu selama 20 menit, adapun luas wilayah $3,52 \mathrm{~km}^{2}$, jumlah penduduk pada tahun 2018 sebanyak 2.269 dengan kepadatan 644.60, jumlah penduduk laki-laki sebanyak 1.217 dan perempuan 1.052 dengan jumlah rumah tangga sebanyak 658, (BPS Kab. Jayapura, 2019). Sebagian besar masyarakat Kampung Yobeh mempunyai mata pencaharian di bidang pertanian sebagai petani sayur, ternak, perkebunan dan perikanan $(70 \%)$, Pegawai Negeri Sipil (10\%), dan swasta dan nelayan (20\%). Nelayan merupakan orang asli Sentani dengan kesehariannya mencari ikan di perairan Danau Sentani, (Siska \& Ressa, 2019).

Danau Sentani terdiri atas tiga bagian, diantaranya ; bagian Sentani Timur, Sentani Tengah, dan Sentani Barat. Kampung Yobeh merupakan bagian dari Sentani Tengah, (Irawati \& Widjaja, 2006). Wilayah Kampung Yobeh terbagi atas pulau dan bagian daratan. Uniknya, Kampung Yobeh memiliki Gereja peninggalan Belanda "Gereja Batu Begal" di pelataran gereja terdapat batu begal, yang terletak di sebuah ceruk. Batu tersebut terbelah dua kiri dan kanan, konon batu ini adalah tempat pemimpin peran meniup Triton (alat musik khas Papua yang terbuat dari cangkang kerang), termasuk adanya batu sakral yang dinamai "Ondi Fnarkoi" batu ini tempat dinobatkannya Kepala Suku, (Detik, 2012). Sebagai potensi di sektor pariwisata, keberadaan "Tifa" merupakan gendang khas Papua yang berusia ratusan tahun berbahan kulit manusia, Tifa sakral ini ada dua jenis, yakni laki-laki dan perempuan, Tifa laki-laki berada di Pulau Yobeh sementara Tifa perempuan diyakini berada di Museum Leiden Belanda. Selain Tifa, para wisatawan juga dapat melihat tombak kuno bersejarah yang hanya digunakan ketika sedang terjadi perang, (Detik, 2013). 
Pada Agustus 2020, Bupati Jayapura Mathius Awoitauw meresmikan Hutan Sagu Huruwakha Kampung Yobeh sebagai tempat wisata. Kawasan hutan sagu tersebut tentunya dapat memanjakan mata bagi para wisatawan, uniknya selain dapat menikmati hutan sagu para pengunjung juga dapat melihat keindahan alam yang disuguhkan Danau Sentani, lantaran lokasinya berdampingan dengan Danau Sentani.

\section{Pelatihan Penyusunan Profil dan Monografi Kampung Yobeh}

Pelaksanaan pelatihan dan pengembangan pengetahuan serta keterampilan yang tertuju untuk pengembangan profil dan monografi Kampung Yobeh, termasuk mengembangkan potensi kampung yang ada dihadiri oleh Kepala Kampung Yobeh Sostinus Sokoy, Sekretaris Kampung Yobeh Aldo Kallem, para Ketua RW dan RT se-Kampung Yobeh, serta tokoh masyarakat setempat. Pada pelaksanaan kegiatan pengabdian masyarakat ini, salah satu kendala yang ditemui dilapangan, yakni adanya ketidak singkron-an data antara Badan Pusat Statistik (BPS) Kabupaten Jayapura dengan hasil penelusuran yang dilakukan pada dokumen kependudukan (Kartu Keluarga), perbedaan data tersebut khususnya mengenai jumlah RT dan RW yang ada di Kampung Yobeh. Hasil temuan tim pelaksana, dengan mengacu pada dokumen kependudukan bahwa Kampung Yobeh memiliki 12 RW dan terdapat 76 RT dengan rincian; RW 1 terdapat 10 RT, RW 2 sampai RW 12 masing-masing memiliki 6 RT. Sementara dengan mengacu pada data BPS Kabupaten Jayapura, Distrik Sentani dalam angka 2019 disebutkan bahwa Kampung Yobeh memiliki 5 RW dan terdapat 12 RT.

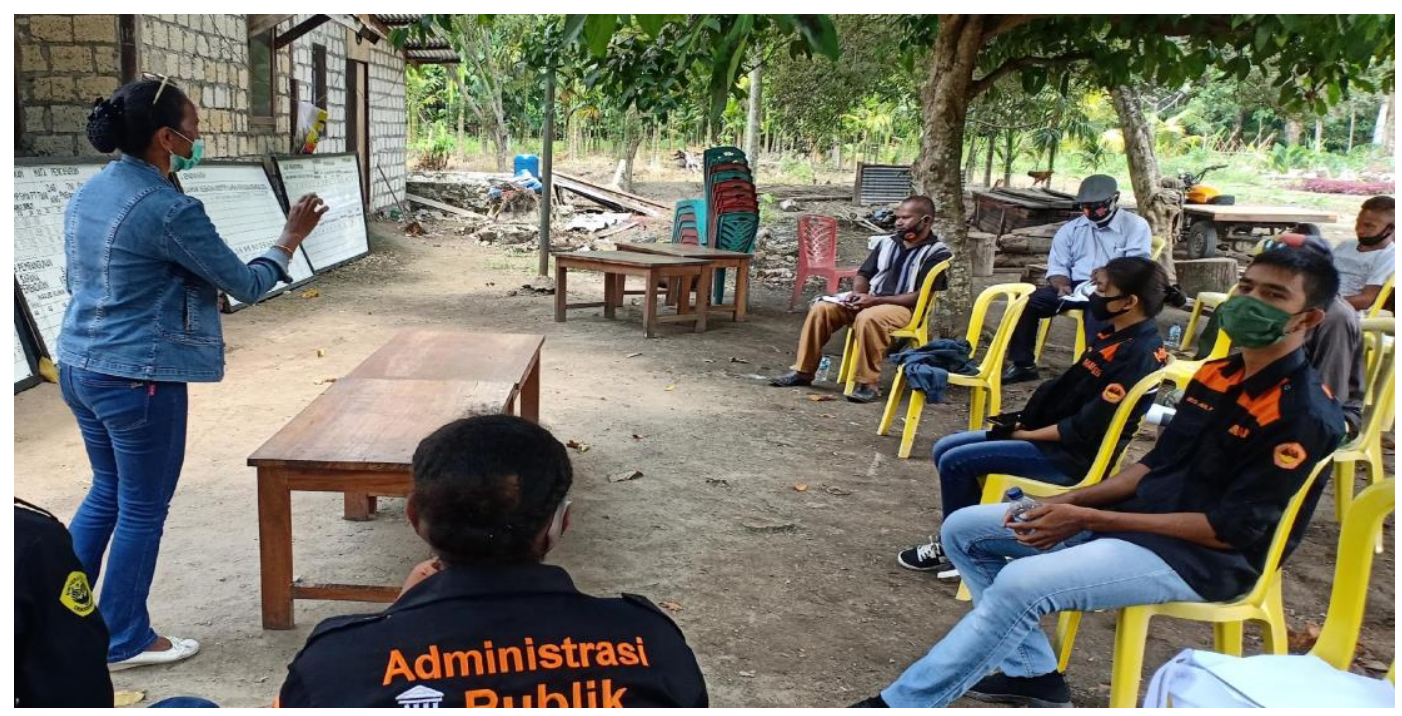

Gambar. 2 : Pelatihan Pengisian Papan Monografi Kampung Yobeh

Menanggapi terkait adanya perbedaan data, khususnya mengenai jumlah RW/RT yang ada di Kampung Yobeh, kemudian ditanggapi Sekretaris Kampung Yobeh Aldo Kallem dengan menyebutkan bahwa:

"Mengenai 5 RW dan 12 RT yang dimaksudkan merupakan data lama, sementara terkait temuan setelah dilakukan penelusuran pada dokumen kependudukan, data tersebut tidaklah akurat atau tidak sesuai. Hal ini terjadi, karena sebagian masyarakat dalam melakukan pengurusan dokumen kependudukan tidak melalui Pemerintah Kampung atau dengan kata lain melakukan pengurusan sendiri-sendiri, sehingga pada saat memasukkan atau diminta data mengenai RW/RT-nya terkadang mereka (masyarakat) asal-asalan dalam menyebutkan, alhasil RW/RT yang kemudian tercantum pada kartu keluarga, tidak tepat".(Wawancara 3 September 2020).

Lebih lanjut Aldo Kallem menyampaikan, bahwa di Kampung Yobeh sebenarnya hanya terdapat $3 \mathrm{RW}$ dan $10 \mathrm{RT}$, sehingga akan dilakukan perbaikan atau pembaruan mengenai pada dokumen kependudukan yang dimiliki warga saat ini. Selanjutnya pembicaraan mengenai 
pelaksanaan pelatihan penyusunan dan penginputan profil dan monografi, Kepala Kampung Yobeh Sostinus Sokoy mewakili aparatur kampung, mengatakan bahwa :

"Sebelumnya kurang paham dengan yang namanya profil dan monografi Kampung bagaimana bentuknya dan seperti apa tujuannya, akan tetapi setelah adanya kegiatan ini sehingga kami menjadi paham. Harapan kami dengan adanya kegiatan seperti saat ini, kehadiran dosen dan anak-anak kita (mahasiswa) kedepannya dapat memperkuat penataan administrasi pemerintahan Kampung”. (Wawancara, 5 September 2020).

Dari penuturun diatas terungkap bahwa selama ini tingkat pemahaman aparatur kampung dalam melakukan penndataan potensi yang ada, begitu juga dengan penyusunan hingga pada saat melakukan penginputan data pada profil dan monografi kampung masih rendah. Melalui pelaksanaan kegiatan pengabdian ini, setidaknya dapat memberikan gambaran ketika aparatur kampung hendak melakukan pembaruan data kedepannya. Mengingat dukungan akurasi data dalam perencanaan pembangunan merupakan hal penting manuju pembangunan yang tepat sasaran. Untuk melahirkan data yang akurat tentunya tak lepas dari perang serta masyarakat untuk turut berpartisipasi aktif didalamnya, sejatinya masyarakat-lah yang lebih paham akan kondisi desa/kampung, adat dan budaya setempat. Menurut Yulius Nyerere dikutip oleh Widodo (2015) mengatakan bahwa pembangunan pedesaan sebagai "partisipasi masyarakat" dalam saling berbagi pengalaman belajar yang melibatkan diri mereka sendiri, sumber-sumber lokal mereka, agen perubahan dari luar dan juga sumber-sumber dari luar wilayah mereka.

Pembangunan desa/kampung mesti sejalan dengan kearifan lokal, dengan adanya keterlibatan masyarakat dalam pemetaan potensi, penyusunan profil dan monografi merupakan cerminan penerapan sistem pembangunan endogen. Pembangunan endogen berarti pembangunan yang dilakukan dari dalam, dimana negara dapat memberikan insentif kepada penduduk untuk berprakarsa secara lokal, asumsinya adalah kegiatan pembangunan tersebut akan mereflesikan bukan hanya kebutuhan lokal akan tetapi juga menyertakan budaya lokal, (Harper 2001; Rhodes 2007; dalam Widodo 2015). Konsep pembangunan endogen ini, menurut hemat penulis sangatlah tepat untuk diterapkan di Papua yang kaya akan tradisi dan budaya lokal.

Pelatihan penyusunan dan penginputan profil dan monografi kampung, sekaligus mengakhiri seluruh rangkaian kegiatan pengabdian kepada masyarakat yang dilaksanakan di Kampung Yobeh oleh dosen dan mahsiswa angkatan 2017 Prodi Ilmu Administrasi Publik, Fisip Univeristas Cenderawasih Jayapura tahun 2020. Penutupan kegiatan ini, ditandai dengan penyerahan papan monografi kampung yang memuat tentang data umum, data personil, data kewenangan, serta data keuangan dan kelembagaan sebagaimana amanat Peraturan Menteri Dalam Negeri (Permendagri) Nomor 13 Tahun 2012 tentang Monografi Desa dan Kelurahan. Termasuk dilakukan pula pembagian ribuan masker kepada masyarakat yang diwakili oleh masing-masing ketua RT seKampung Yobeh, mengingat masa pandemi Covid-19 belum berakhir.

\section{SIMPULAN}

Profil kampung selain memuat data dasar keluarga, sarana/prasarana dan kelembagaan, termasuk didalamnya membahas mengenai potensi yang dimiliki kampung baik dari segi sumber daya alam, sumber daya manusia, begitu juga dengan perkembangan kemajuan dan permasalahan yang dihadapi Kampung Yobeh. Sehingga pelibatan masyarakat dalam penyusunan profil kampung merupakan bentuk pemberdayaan masyarakat agar turut berpartisipasi aktif dalam setiap perencanaan pembangunan. Dapat disimpulkan bahwa profil dan monografi kampung merupakan bentuk penerapan model pembangunan partisipatif berbasis kearifan lokal, dengan tidak mengabaikan adat istiadat dan budaya masyarakat setempat. Melalui pelibatan masyarakat yang notabene lebih paham akan kondisi alam, budaya lokal dan adat istiadat juga merupakan cerminan penerapan konsep pembangunan endogen, yang dilakukan dari dalam.

Selanjutnya melalui monografi kampung selain menyajikan data administrasi kampung secara umum, personal, kewenangan, kelembagaan termasuk di dalamnya adalah memuat tentang keuangan Kampung. Sehingga hadirnya monografi kampung merupakan salah bentuk transparansi pengelolaan keuangan kepada masyarakat, baik mengenai pendapatan, belanja, pembiayaan dan kekayaan kampung. Persoalannya kemudian adalah profil dan monografi kampung terkadang 
dipandang hanya sebatas kebutuhan administrasi yang harus dipenuhi, sehingga terkadang tidak dilakukan pembaruan, termasuk pemahaman aparatur kampung mengenai profil dan monografi juga dianggap masih rendah.

Disatu sisi, kemampuan dan tingkat pemahaman aparatur kampung dalam menyusun profil dan monografi merupakan salah satu faktor pendukung dalam menyajikan data yang akurat dan aktual. Keakuratan data akan melahirkan kebijakan pembangunan yang tepat sasaran sesuai dengan kebutuhan masyarakat setempat. Pembangunan yang tepat sasaran tentunya akan berpangkal terhadap kesejahteraan masyarakat. Sebagai catatan penutup, pembangunan tanpa data ibarat berjalan di tengah gemerlapnya malam, data ibarat penerang menuju pembangunan yang tepat sasaran yang tentunya sesuai dengan kondisi, budaya dan adat istiadat masyarakat di tingkat kampung.

\section{SARAN}

Sebagai rekomendasi, pihak terkait perlu melakukan pembekalan melalui pendidikan dan pelatihan (diklat) yang ditujukan bagi perangkat kampung dalam memetakan potensi, menyusun dan mengisi profil dan monografi kampung. Termasuk perlu adanya edukasi untuk meningkatkan kesadaran dan partisipasi masyarakat agar melaporkan ketika terjadi perubahan-perubahan data kepada aparat atau pemerintah kampung. Keterbukaan, kesadaran dan partisipasi masyarakat dalam memberikan informasi menjadi bagian penting dalam menghadirkan penyajian data yang akurat dan aktual.

\section{UCAPAN TERIMA KASIH}

Atas terselenggaranya kegiatan pengabdian kepada masyarakat tersebut, maka segenap tim pelaksana dosen dan mahasiswa angkatan 2017 Prodi Ilmu Administrasi Publik, Fakultas Ilmu Sosial dan Ilmu Politik Universitas Cenderawasih Jayapura mengucapkan banyak terima kasih kepada seuluruh pihak yang terlibat. Khususnya, kepada Kepala Kampung Yobeh Sostinus Sokoy, Sekretaris Kampung Yobeh Aldo Kallem, para Ketua RW dan RT se-Kampung Yobeh, serta tokoh masyarakat dan masyarakat Kampung Yobeh atas bantuan, partisipasi dan dukungannya sehingga setiap program yang telah terencana dapat berjalan dengan baik. Kegiatan ini tentunya memiliki celah ketika mencari kekurangan di dalamnya, termasuk dalam penulisan artikel tersebut. Untuk itu, kritik dan saran yang sifatnya membangun senantiasa kami harapkan dalam melakukan perbaikan pada kegiatan-kegiatan di masa mendatang.

\section{DAFTAR PUSTAKA}

Anangkota, M. (2013). Reposisi Distrik Di Papua; Perspektif Kebijakan Penataan Kewenangan. Jurnal Kebijakan Publik, 1(1), 45-52.

Badan Pusat Statistik. (2019). Distrik Sentani Dalam Angka 2019. Badan Pusat Statistik Kabupaten Jayapura

Detikcom. (2020). Jumlah Penduduk Dunia 2020, Indonesia Masih Empat Besar. [Online] Available At ; https://travel.detik.com/detiktravel/d-5152094/jumlah-penduduk-dunia-2020indonesia-masih-empat-besar. (Accessed Sept, 22 2020).

,(2012). "Ketika Yobeh Membuka 'Cadarnya". [Online] Available At : https://travel.detik.com/destination/d-1956271/ketika-yobeh-membuka-cadarnya. (Accessed Sept, 24 2020).

,(2013). "Kisah Tifa Keramat dari Kulit Manusia di Sentani". [Online] Available At ; https://travel.detik.com/destination/d-2283135/kisa-tifa-keramat-dari-kulit-manusia-di-

sentani. (Accessed Sept, 24 2020)

Ilham, M. Z. Muttaqin, U. Idris. (2020). Pengembangan Bumkam Berbasis Potensi Lokal Di Kawasan Perbatasan Indonesia-Papua New Guinea. Community Development Journal, 1(2), 104-109.

Irawati, Dyah \& Hinijati Widjaja, (2006). Eksistensi Sosial-Politik Dewan Adat Papua dalam Pemberdayaan Masyarakat (Studi Kasus Dewan Adat Sentani di Sentani, Kabupaten Jayapura). Jakarta : UKI Press.

Jayapurakab.go.id. (2017). "Penutupan Pelatihan POAP17-K". [Online] Available At; 
https://jayapurakab.go.id/penutupan-pelatihan-poap17-k.html. (Accessed Sept, 22 2020).

Masterplandesa.com. (2020). "Monografi dan Profil Desa: Belajar dari Dusun Serut". [Online] Available At : https://www.masterplandesa.com/profil-desa/monografi-dan-profil-desabelajar-dari-dusun-serut/. (Accessed Sept, 22 2020).

Pemerintah Indonesia, (2007). Peraturan Menteri Dalam Negeri Nomor 12 Tahun 2007 tentang Pedoman Penyusunan Dan Pendayagunaan Data Profil Desa Dan Kelurahan.

, (2012). Peraturan Menteri Dalam Negeri Republik Indonesia Nomor 13 Tahun 2012 tentang Monografi Desa Dan Kelurahan.

Setkab.go.id.(2019)."Membangun Indonesia Dari Pinggiran Desa". [Online] Available At: https://setkab.go.id/membangun-indonesia-dari-pinggiran-desa/. (Accessed Sept, 22 2020).

Siska \& Ressa. (2019). "Koordinasi Awal Kegiatan Pendampingan Ayam KUB di Kampung Yobeh Sentani". [Online] Available At : http://papua.bptpnews.id/Portal/detailBerita/627. (Accessed Sept, 24 2020).

Turmudi, H , Harun \& Nurhadiantomo. (2017). Desa Dan Otonomi Asli (Studi tentang Perangkat Desa Menuju Terciptanya Desa yang Berotonomi Asli). Thesis, Universitas Muhammadiyah.

Widodo, Teguh. (2015). Pembangunan Endogen : Mengabaikan Peran Negara dalam Pembangunan. Ed.1, Cet.1 . Yogyakarta : Deepublish.

Wirayadnya, N. B. (2011). "Jumlah Penduduk Tidak Pernah Akurat". [Online] Available At: https://metrobali.com/jumlah-penduduk-tidak-pernah-akurat/. (Accessed Sept, 23 2020). 